\title{
Relasi Kurikulum dan Pembelajaran serta Kontekstualisasinya dengan Nilai-Nilai Multikultural
}

\author{
Winarto Eka Wahyudi \\ Universitas Islam Lamongan \\ Email: ekawahyudi1926@unisla.ac.id
}

\section{Article History:}

Received: 09-08-2019

Revised: 20-08-2019

Accepted: 05-09-2019

\begin{abstract}
This article discusses the relationship between curriculum and teaching and its contextualisation in learning with multicultural values. This study is very relevant considering that Indonesia is a nation that consists of diverse ethnic groups and is rich in cultural and religious differences. This anthropological inevitability requires an ability that is compatible with existing cultural realities. In this context, education plays an important role in giving birth to people who do not stutter from differences. To that end, designing a curriculum with multicultural values while translating it into the learning process is an effort to continue to be actualized. The relational model between curriculum and teaching that allows in internalizing multicultural values includes: the dualistic model, the interlocking model, the concentric model and the cycle model.
\end{abstract}

Keyword: curriculum, instructional, multicultural

\section{Pendahuluan}

Kurikulum memiliki pengertian yang bervariasi, mulai dari peaknaan yang mendasarkan pada bahan atau materi pelajaran yang akan diberikan oleh pengajar kepada para peserta didik, hingga kurikulum yang dianggap sebagai segala pengalaman yang telah direncanakan untuk dialami oleh peserta didik dalam proses belajarnya. Di sisi lain, kurikulum juga mengandung beberapa komponen-komponen yang membentuknya, seperti tujuan, isi, organisasi, metode, dan evaluasi kurikulum. Dalam konteks ini dapat dpahami bahwa eksistensi kurikulum tentu sangat erat hubungannya dengan proses pembelajaran, sebab di dalam kurikulum tercantum hal-hal yang nantinya dapat memengaruhi proses pembelajaran itu sendiri.

Namun, ketika dihadapkan pada konteks di lapangan yang meniscayakan entitas beragam baik dari lingkungan pendidikan maupun peserta didik, maka model dan desain pembelajaran yang mengapresiasi nilai-nilai diversitas atau multikultur menjadi relevan. Untuk itulah diperlukan kajian konseptual mengenai hubungan antara kurikulum dengan pengajaran berbasis multikultural.

Di dalam makalah ini, penulis akan menyajikan pembahasan mengenai konsep dasar kurikulum dan pembelajaran beserta hubungan antara keduanya, serta dimensi multikultural yang harus diperhatikan dalam proses pembelajaran. Untuk itu, dalam kajian ini penulis penulis perlu membuat rumusan masalah untuk menfokuskan pembahasan agar tidak terjadi over-lapping dalam pemaparan dalam makalah kali ini. 


\section{Kurikulum dan Pengajaran: Tinjauan Konseptual}

Al-Syaibany mendifinisikan bahwa kurikulum terbatas pada pengetahuanpengetahuan yang dikemukakan oleh guru atau institusi pendidikan lainnya dalam bentuk mata pelajaran atau kitab-kitab karya para ulama terdahulu yang dikaji begitu lama oleh para peserta didik dalam tiap tahap pendidikannya. ${ }^{1}$ Selain itu, Peter F. Olivia, sebagaimana dikutip Muhaimin mendifinisikan kurikulum sebagai rencana atau program yang menyangkut semua pengalaman yang dihayati peserta didik dibawah pengerahan guru, managemen sekolah atau pergururan tinggi. ${ }^{2}$

Dua definisi tentang kurikulum di atas sudah cukup mewakili definisi kurikulum secara umum, karena pada umumnya kurikulum didefinisikan dalam dua definisi yang sedikit berbeda, yang satu menekankan kurikulum terbatas pada materi pelajaran, dan yang lain menekankan pada segala aspek pengalaman yang menjadi proses belajar bagi peserta didik. Namun keduanya sama-sama mengandung pengertian bahwa kurikulum adalah rencana belajar.

Sementara itu, Abdullah Idi berpendapat bahwa kurikulum memiliki beberapa pengertian yang memiliki perbedaan satu sama lain. karena menurutnya, kurikulum bisa diartikan sesuai dengan konteks dari mana kurikulum itu diimplementasikan. ${ }^{3}$ Adapun beberapa pengertian tersebut adalah sebagai berikut;

1. Kurikulum sebagai bahan pelajaran (curriculum as subject matter)

Pengertian ini berimplikasi pada kurikulum yang diaktualisasikan sebagai bahan ajar

(subject matter). Pengertian ini merupakan pengertian kurikulum yang paling tradisional dan sederhana. Kurikulum dalam konteks ini digambarkan sebagai kombinasi dan komposisi bahan ajar yang akan diberikan kepada peserta didik.

2. Kurikulum sebagai pengalaman (curriculum as experience)

Dalam pengertian ini, kurikulum dideskripsikan sebagai seperangkat pengalaman yang telah dirancang oleh pendidik untuk proses pembelajaran peserta didik.

Sementara itu, Nasution mengutip pengertian Hilda Tabamemberikan pemaknaan berbeda mengenai kurikulum. Ia mengatakan bahwa curriculum is a plan for learning 4 Namun, definisi Taba ini sangat sempit karena hanya memaknai kurikulum sebagai perencanaan sebelum proses pembelajaran saja. Definisi agak luas pernah dikemukakan oleh Saylor \& Alexander yang menyatakan bahwa curriculum is the total effort of the school to achieving about desired outcomes in school and out of the school situation. Dilihat dari definisi ini, nampaknya Saylor ingin menjelaskan bahwa kurikulum sejatinya merupakan segala macam usaha yang dilakukan oleh sekolah untuk mencapai tujuan yang dinginkan baik usaha itu dilakukan di dalam atau di luar sekolah. ${ }^{5}$

Namun dalam konteks pendidikan multikultural, pengertian yang relevan adalah sebagaimana yang dilontarkan oleh Smith yang menekankan aspek sosial dalam konteks kurikulum. Ia mendefinisikan kurikulum sebagai usaha tentang bagaimana mendidik

\footnotetext{
${ }^{1}$ Muhaimin, Pengembangan Kurikulum Pendidikan Agama Islam, (Jakarta : Rajawali Pers, 2010), 2.

${ }^{2}$ Ibid., 3.

${ }^{3}$ Abdullah Idi, Pengembangan Kurikulum Teori Dan Praktek, (Jogjakarta : Ar-Ruzz Media, 2011), 47.

${ }^{4}$ Nasution, Pengembangan Kurikulum (Bandung: Alumni, 1988), 10.

${ }^{5}$ Ibid., 9.
} 
peserta didik cara berfikir dan berbuat sebagai anggota masyarakat. Tentu saja, pengetian ini berimplikasi pada pertimbangan-pertimbangan norma universal yang berlaku di masyarakat saat melakukan aktifitas berfikir dan bertindak. ${ }^{6}$

Sedangkan definisi kurikulum yang lebih luas dikemukakan oleh John Kerr yang mengatakan bahwa kurikulum memuta pengalaman belajar (learning experience) peserta didik, baik individual maupun kelompok, di dalam maupun di luar sekolah dengan bimbingan guru atatu sekolah secara lebih umum. (all the learning which a planned and guide by the school, whether it is carried on in groups or individually, inside or outside the school $)^{7}$

Selanjutnya, setalah konsep dasar kurikulum dapat dipahami melalui pemaparan sekilas di atas, maka yang perlu untuk diketahui lebih lanjut adalah tentang konsep dasar pembelajaran sebagai bentuk manifestasi kurikulum pada tataran praksis. Dari makna dasarnya, pembelajaran berasal dari akar kata belajar, yang mengindikasikan adanya aktifitas pemerolehan pengetahuan. Jika belajar identik dimaknai sebagai aktiffitas yang terlahir dari dorongan internal, maka pembelajaran merupakan aktifitas akademik yang timbul dari interaksi antara pendidik sebagai pengajar dan peserta didik sebagai pembelajar. Definisi ini menurut penulis, merupakan aktifitas transformasi ilmu pengetahuan yang didorong oleh faktor-faktir eksternal. Jadi, dapat dipahami bahwa antara pembelajaran dengan belajar memiliki hubungan yang erat.

Pembelajaran dalam konteks pemaknaan di atas, tentu sangat kuat kaitannya dengan kurikulum, di mana kurikulum itu sendiri berfungsi sebagai perencanaan tentang pengalaman belajar apa yang akan diberikan kepada peserta didik. ${ }^{8}$ Di satu sisi kurikulum adalah rencana tertulis yang telah dibukukan oleh para pengembang kurikulum yang nantinya akan menjadi tuntunan bagi para pengajar dalam melaksanakan proses pengajaran, pada posisi ini pembelajaran berdampak pada out put berupa hasil belajar yang nanti akan dievaluasi dan berguna dalam perencanaan dan perancangan kurikulum selanjutnya.

\section{Kurikulum dan Pembelajaran: Analisa Korelasional}

Kurikulum dan pembelajaran merupakan dua hal yang tidak terpisahkan, meski berada pada posisi yang berbeda. Konon, ada yang menganalogikan bahwa kurikulum dan pembelajaran bagaikan romeo dan juliet. Jika kita berbicara tentang Romeo, maka kita juga akan berbicara masalah Juliet. Romeo tidak akan lengkap tanpa juliet, demikian pula sebaliknya. Artinya, pembelajaran tanpa kurikulum sebagai rencana tidak akan efektif, atau bahkan bisa keluar dari tujuan yang telah dirumuskan. Kurikulum tanpa pembelajaran, maka kurikulum tersebut tidak akan berguna.

Selain itu, Olivia menyatakan bahwa kurikulum berkaitan dengan apa yang harus diajarkan, sedangkan pengajaran mengacu pada bagaimana cara mengajarkannya. ${ }^{9}$

3.

${ }^{6}$ Lebih lengkap lihat dalam Mark K. Smith, Curriculum Theory and Practice (London: Routladge, 2002),

${ }^{7}$ Ibid., 4.

${ }^{8}$ Moh. Ali, Pengembangan Kurikulum di Sekolah, (Jakarta : CV. Sinar Baru, 1992), 2

${ }^{9}$ Peter F. Oliva, Developing the Curriculum, third edition. (New York. Harper Collins Publishers, 1992), 
Walaupun antara pembelajaran dengan pengajaran dalam hal ini memiliki perbedaan, namun keduanya memiliki kesamaan tolak ukur dalam kasus ini, yaitu bagaimana mengajarkan. Hanya saja pengajaran lebih terpusat pada guru sebagai pengajar, sedangkan pembelarajaran menekankan pada penciptaan proses belajar antara pengajar dengan pelajar agar terjadi aktivitas belajar dalam diri pelajar.

Belajar sebagai kegiatan inti dari pembelajaran memiliki arti modifikasi atau memperteguh kelakuan melalui pengalaman. ${ }^{10}$ Yang perlu digaris bawahi pada kalimat tersebut adalah memperteguh kelakuan melalui pengalaman, ini membuktikan bahwa belajar sebagai kegiatan inti pembelajaran dipengaruhi oleh kurikulum yang notabenenya merupakan rancangan pengalaman belajar.

Persoalan yang timbul selanjutnya adalah bagaimana menyusun kurikulum untuk kepentingan pembelajaran agar dapat dilaksanakan dengan optimal sesuai dengan tujuan pembelajaran yang direncanakan? Hal ini berbenturan dengan fakta bahwa kurikulum telah dirancang secara standar (standarized curriculum), yaitu melalui ketetapan pemerintah yang merumusakan tujuan pembelajaran melalaui SKL. Ini berarti bahwa kurikulum yang sama digunakan pada setiap sekolah yang notabenenya masing-masing sekolah tersebut memiliki masalah pelaksanaan pembelajaran yang berbeda. Maka dari itu diperlukan pengembangan seperlunya yang disesuaikan dengan kondisi disekolah. Hal ini bisa dilakukan melalui perumusan Rencana Pembelajaran.

Mengenai keterhubungan antara kurikulum dan pembelajaran Oliva menggambarkan melalui beberapa model sebagai berikut: ${ }^{11}$

\section{Model dualistis (the dualistic model)}

Pada model ini kurikulum dan pengajaran terpisah. Keduanya tidak bertemu. Kurikulum yang seharusnya menjadi input dalam menata sistem pengajaran tidak tampak. Demikian juga pengajaran yang semestinya memberikan balikan dalam proses penyempurnaan kurikulum tidak terjadi, karena kurikulum dan pengajaran berjalan sendiri. Pada model dualistik, implementasi proses belajar mengajar yang dikendalikan oleh guru tidak dikaitkan dengan perencanaan program kurikulum, walaupun mungkin sebenarnya berkaitan. Pembuat kurikulum mengabaikan para pengajar demikian juga para pengajar mengabaikan program kurikulum. Pada model dualistik ini, kurikulum dan proses pembelajaran mungkin berubah tanpa saling mempengaruhi satu sama lain secara singnifikan.

Adapun kelebihan dari model ini adalah dengan adanya pemisahan pada model dualistic ini, kurikulum dan pembelajaran dapat lebih leluasa dikembangkan sesuai dengan kebutuhan dilapangan. Pembelajaran tidak kaku karena bisa digerakan tanpa harus mengacu pada kurikulum. Kekurangan dari model ini terdapat pemisahan kurikulum dan pembelajaran. Dengan demikian tentu tidak akan ada kesamaan dan keseiringan laju kurikulum dan pembelajaran sehingga tentu program pembelajaran dan prakteknya akan berlainan. Model ini digambarakan sebagai berikut :

\footnotetext{
${ }^{10}$ Oemar Hamalik, Proses Belajar Mengajar, (Jakarta : PT Bumi Aksara, 2011), 27.

${ }^{11}$ Peter F. Olivia, 54.
} 

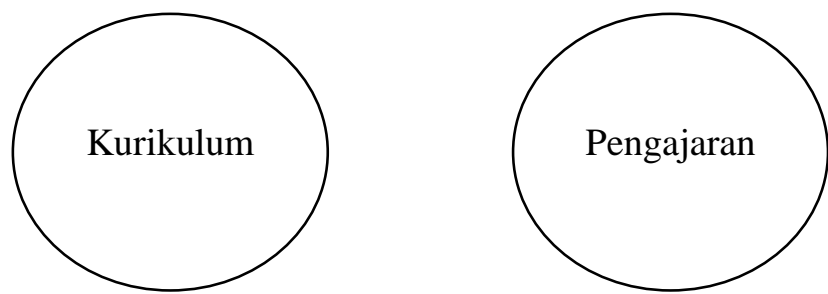

\section{Model berkaitan (the interlocking model)}

Dalam model ini kurikulum dan pengajaran dianggap sebagai suatu sistem yang keduanya memiliki hubungan. Kurikulum dan pengajaran maupun sebaliknya pengajaran dan kurikulum menjadi dua hal yang berkaitan antara satu degan yang lain, sehingga keduanya memiliki hubungan. Pada model interlocking, kurikulum dan pembelajaran memiliki posisi yang sama. Keduanya saling mempengaruhi, pemisahan dari keduanya dianggap akan membahayakan. Keberhasilan pembelajaran dianggap dipengaruhi oleh perencanaan kurikulum yang baik, sebaliknya perencanaan kurikulum yang baik harus mempertimbangkan pembelajarannya.

Kelebihan model ini mengaitkan kurikulum dan pembelajaran, memandang antara keduanya tidak bisa dipisahkan. Hal ini tentu membuat proses pendidikan menjadi selaras, dimana program dan praktek pembelajaran menjadi saling terkait dan mempengaruhi.

Sedangkan Kekurangan dengan model ini, dikhawatirkan akan adanya proses pendidikan yang kaku. Artinya, pengembangan kurikulum dan pelaksaa pembelajaran dipaksakan untuk selaras sehingga pembuat kurikulum tidak dengan leluasa mengembangkan kurikulumnya, dan pelaksana pembelajaran terlalu berfokus pada program yang telah ditulis dalam dokumen kurikulum. Model ini digambarkan sebagai berikut :

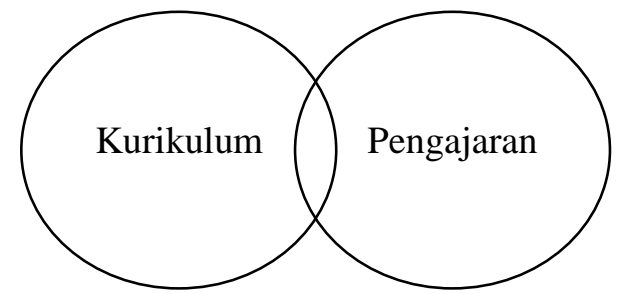

\section{Model konsentris (the concentric model)}

Pada model ini kurikulum dan pengajaran memiliki hubungan dengan kemungkinan kurikulum bagian dari pengajaran atau pengajaran bagian dari kurikulum. Di sini ada ketergantungan satu dengan yang lain. salah satu dari keduanya merupakan subsistem dari yang lainnya. Pada model ini banyak ahli berpendapat bahwa kurikulum lebih dominan dan pembelajaran sebagai subordinatnya. Sementara para ahli yang lain mengatakan bahwa pembelajaran lebih dominan dan kurikulum sebagai subordinatnya.

Dengan adanya lingkup besar dan kecil (dominan dan subordinat) dari kurikulum dan pembelajaran ini, memberikan batasan lingkup kajian masing-masing. Terlepas dari kurikulum atau pembelajaran yang menjadi dominan, namun keduanya akan bergerak 
sesuai dengan wilayah cakupannya masing-masing. Namun penulis dalam makalah ini memandang bahwa kurikulum lebih dominan dibanding pembelajaran. Dengan demikian kurikulum memberikan kontrol atas pelaksanaan pembelajaran. Model konsentris ini digambarkan sebagai berikut :
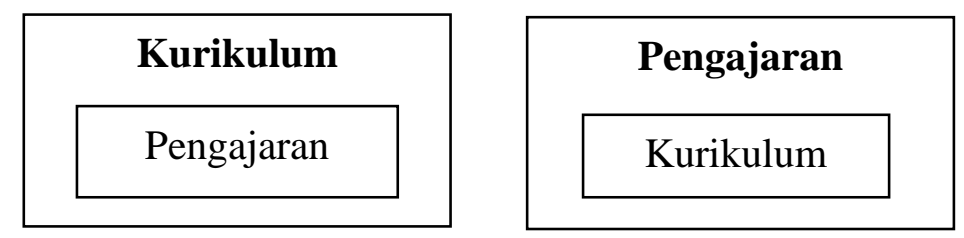

\section{Model Siklus (the ciclical model)}

Model ini menggambarkan hubungan timbal balik antara kurikulum dan pengajaran. Keduanya dianggap saling mempengaruhi. Segala yang ditentukan dalam kurikulum akan menjadi dasar dalam proses pelaksanaan pengajaran. Sebaliknya yang terjadi dalam pengajaran dapat memengaruhi keputusan kurikulum selanjutnya. Dalam model ini hubungan keduanya sangat erat meski kedudukannya terpisah yang berarti dalam analisis juga terpisah. Digambarkan sebagai berikut :

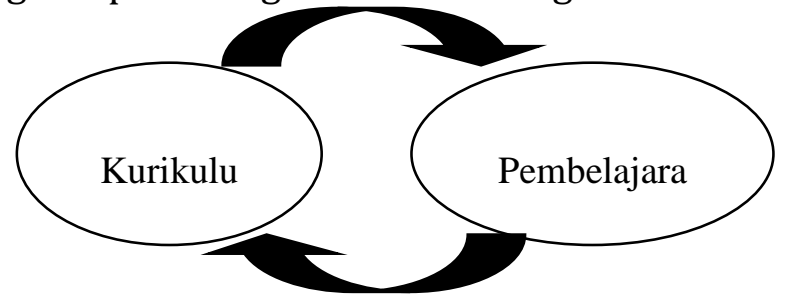

Melihat beberapa bentuk model hubungan antara Pembelajaran kurikulum di atas, maka dapat dipahami bahwa eksistensi pendidikan sebagai hajat kehidupan, sangat erat kaitannya dengan pola korelasional antara kurikulum sebagai blue print dan pembelajaran sebagai "aksi pendidikan" karena proses pembelajaran tanpa adanya kurikulum sebagai program atau acuan, akan terbengkalai sehingga akan berkonsekuensi pada semakin jauhnya dalam pencapaian tujuan pendidikan yang menjadi cita-cita jangka panjangnya.

\section{Nilai-Nilai Multikultural dalam Kurikulum}

Pada dasarnya, pembelajaran berbasis multikultural didasarkan pada gagasan filosofis tentang kebebasan, keadilan, kesederajatan dan perlindungan terhadap hak-hak manusia. Hakekat pendidikan multikultural pada konteks filofis ini, mengorientasikan terhadap peserta didik untuk belajar secara aktif menuju kesamaan struktur dalam organisasi dan lembaga sekolah. Pendidikan multikultural bukan sebuah kebijakan yang mengarah pada pelembagaan pendidikan dan pengajaran inklusif yang dimaksudkan dalam rangka melakukan propaganda pluralisme melalui kurikulum yang berperan sebagai pembentuk kompetensi budaya individual.

Dalam tataran regulatif, pemerintah sebenarnya sudah menjadikan isu multikultural dalam kebijakannya yang dituangkan dalam Undang-Undang Sisdiknas No 20 Tahun 2003, sehingga dalam konteks ini sesungguhnya pendidikan multikultural tak lain merupakan penerjemahan dari UU tersebut, yang mengamanatkan bahwa pendidikan nasional harus diselenggarakan secara demokratis dan berkeadilan serta 
tidak diskriminatif dengan menjunjung tinggi hak asasi manusia, nilai keagamaan, nilai kultural, dan kemajemukan bangsa. ${ }^{12}$

Selain itu, pembelajaran berbasis multikultural dalam hal ini merupakan usaha untuk memberdayakan siswa dalam rangka mengembangkan rasa hormat kepada orang yang memiliki diferensiasi kultural, selain itu pembelajaran multikultural juga diorientasikan kepada pemberian kesempatan untuk bekerja bersama dengan orang atau kelompok orang yang berbeda etnis atau ras secara langsung. Pendidikan dengan mengedapankan dan mempertimbangkan realitas multikultural, juga membantu siswa untuk mengakui fakta dari pandangan-pandangan budaya yang beragam, membantu siswa dalam mengembangkan kebanggaan terhadap warisan budaya mereka, menyadarkan siswa bahwa konflik nilai primordial sering menjadi penyebab konflik antar kelompok masyarakat. ${ }^{13}$

Pendidikan multikultural dalam hal ini, diselenggarakan sebagai upaya membentuk dan mengembangkan kemampuan siswa dalam memandang kehidupan dari berbagai perspektif budaya yang berbeda dengan budaya yang mereka miliki, sekaligus bersikap positif terhadap perbedaan budaya, ras, dan etnis. ${ }^{14}$ Adapun tujuan pengajaran dengan berbasis pada keniscayaan multikultural dapat diidentifikasi sebagai berikut:

1. Untuk memfungsikan peranan sekolah dalam memandang keberadaan siswa yang beraneka ragam;

2. Untuk membantu siswa dalam membangun perlakuan yang positif terhadap perbedaan kultural, ras, etnik, kelompok keagamaan;

3. Memberikan ketahanan siswa dengan cara mengajar mereka dalam mengambil keputusan dan keterampilan sosialnya;

4. Untuk membantu peserta didik dalam membangun ketergantungan lintas budaya dan memberi gambaran positif kepada mereka mengenai perbedaan kelompok. ${ }^{15}$

Pada tataran yang lebih tinggi, sejatinya pembelajaran dengan mengedepankan nilai-nilai multikultural banyak memiliki urgensinya yang penting dalam konteks untuk menciptakan kondisi sosial yang lebih baik. Pada tataran ini, pendidikan multikultural memiliki keutamannya sendiri, antara lain:

1. Memberikan terobosan baru pembelajaran yang mampu meningkatkan empati dan mengurangi prasangka siswa atau mahasiswa sehingga tercipta manusia (warga negara) antarbudaya yang mampu menyelesaikan konflik dengan tanpa kekerasan (nonviolent);

2. Menerapkan pendekatan dan strategi pembelajaran yang potensial dalam mengedepankan proses interaksi sosial dan memiliki kandungan afeksi yang kuat;

12 Undang-Undang Sistem Pendidikan Nasional No 20 Tahun 2003 BAB III tentang Prinsip Penyelenggaraan Pendidikan Pasal 4 ayat 1.

${ }^{13}$ T.V Savage \& Armstrong, D.G, Effective Teaching in Elementary Social Studies (Ohio: Prentice Hall, 1996), 17.

${ }^{14}$ P.J Farris \& S.M Cooper, Elementary Social Studies: a Whole language Approach (Iowa: Brown \& Benchmark Publishers, 1994), 27.

${ }^{15}$ James .A. Banks,. "Multikultural Educatian: Historical Development, Dimentions and Practrice" In Review of Research in Education, vol. 19, edited by L. Darling- Hammond. (Washington, D.C.: American Educational Research Association, 1993), 28, dan D.J Skeel,. Elementary Social Studies: Challenge for Tomarrow"s World (New York: Harcourt Brace College Publishers, 1995), 53. 
3. Model pembelajaran multikultural membantu guru dalam mengelola proses pembelajaran menjadi lebih efisien dan efektif, terutama memberikan kemampuan peserta didik dalam membangun kolaboratif dan memiliki komitmen nilai yang tinggi dalam kehidupan masyarakat yang serba majemuk;

4. Memberikan kontribusi bagi bangsa Indonesia dalam penyelesaian dan mengelola konflik yang ernuansa SARA yang timbul di masyarakat dengan cara meningkatkan empati dan mengurangi prasangka. Kondisi keberagaman masyarakat dan budaya, secara positif menggambarkan kekayaan potensi sebuah masyarakat yang bertipe pluralis, namun secara negatif orang merasa tidak nyaman karena tidak saling mengenal budaya orang lain. Setiap etnik atau ras cenderung mempunyai semangat dan ideologi yang etnosentris, yang menyatakan bahwa kelompoknya lebih superior daripada kelompok etnik atau ras lain. ${ }^{16}$

Selanjutnya, kenyataan bahwa tidak semua siswa antara satu dengan yang lain tidak saling mengenal dan memahami identitas budaya orang lain, berpotensi mendorong meningkatnya prasangka terhadap orang lain, berupa sikap antipati yang didasarkan pada kesalahan generalisasi yang diekspresikan sebagai perasaan. Prasangka negative tersebut, terkadang juga diarahkan kepada sebuah kelompok secara keseluruhan, atau kepada seseorang hanya karena itu adalah anggota kelompok tertentu. Dengan demikian, prasangka memiliki potensi dalam mengambinghitamkan orang lain melalui stereotype yang bernuansa peyoratif, dan diskriminasi sehingga berdampak pada terciptanya jarak sosial. ${ }^{17}$

Untuk mengatasi fenomena ini, sesungguhnya pemerintah telah memberikan rambu melalui Peraturan Menteri Pendidikan yang salah satu poin pentingnya dalam kelompok mata pelajaran Kewarganegaraan dan Kepribadian untuk Kelompok mata pelajaran kewarganegaraan dan kepribadian dimaksudkan untuk peningkatan kesadaran dan wawasan peserta didik akan status, hak, dan kewajibannya dalam kehidupan bermasyarakat, berbangsa, dan bernegara, serta peningkatan kualitas dirinya sebagai manusia. Kesadaran dan wawasan termasuk wawasan kebangsaan, jiwa dan patriotisme bela negara, penghargaan terhadap hak-hak asasi manusia, kemajemukan bangsa, pelestarian lingkungan hidup, kesetaraan gender, demokrasi, tanggung jawab sosial, ketaatan pada hukum, ketaatan membayar pajak, dan sikap serta perilaku anti korupsi, kolusi, dan nepotisme. ${ }^{18}$

Melalui pembelajaran multikultural, subyek belajar dapat mencapai kesuksesan dalam mengurangi prasangka dan diskriminasi. Dengan kata lain, sekolah mempunyai variabel yang seimbang dalam memperlakukan antar kelompok rasial dan etnis yang memiliki pengalaman dan hak yang sama dalam proses pendidikan. Pelajar mampu mengembangkan keterampilannya dalam memutuskan sesuatu secara bijak. Konsekuensi positif yang ditimbulkan adalah mereka lebih banyak menjadi subyek dari

${ }^{16}$ Alo Liliweri, Prasangka \& Konflik: Komunikasi Lintas Budaya Masyarakat Multikultural. (Yogyakarta: LKiS, 2005), 34.

${ }^{17}$ C. Bennett, \& E Spalding, "Teaching the Social Studies: Multiple Approaches for Multiple Perspectives" In Theory and Reseach in Social Education, 1992), 263-292.

${ }^{18}$ Peraturan Menteri Pendidikan Nasional No 22 Tahun 2006 tentang Standart Isi untuk Satuan Pendidikan Dasar dan Menengah pada BAB II pada bahasan Kerangka Dasar dan Struktur Kurikulum, 2. 
pada menjadi obyek dalam suatu kurikulum. Mereka menjadi individu yang mampu mengatur dirinya sendiri dan merefleksi kehidupan untuk bertindak secara aktif.

Di sisi lain, mereka juga bisa membuat keputusan dan melakukan sesuatu yang berhubungan dengan konsep, pokok-pokok masalah yang mereka pelajari. Mereka akan mampu secara mandiri mengembangkan visi sosial yang lebih baik dan memperoleh ilmu pengetahuan dan keterampilan serta mengkonstruksinya dengan sistematis dan empatis.

Kemudian, dalam kaitannya dengan penyusunan kurikulum pendidikan multikultural, ada beberapa hal yang harus diperhatikan: ${ }^{19}$

Pertama, penyusunan kurikulum harus didasarkan kepada keimanan pada Tuhan Yang Maha Esa, norma-noram, atau nilai-nilai absolute yang diambil dari agama-agama besar di dunia dan hubungan integral antara Tuhan, manusia, dan alam.

Kedua, karena ilmu pengetahuan dari Tuhan, manusia tidak dapat disebut sebagai pembuat ilmu pengetahuan. Namun, karena manusia dapat dengan mudahnya menemukan aspek-aspek yang terkandung di dunia ini, maka nilai-nilai kemanusiaan dapat dijadikan sebagai inspirasi untuk menyeleksi, menginvestigasi, dan menikmati adanya sebuah kebenaran.

Ketiga, peserta didik diharuskan mengetahui hierarki antara ilmu pengetahuan dan sumber nilai. Ilmu pengetahuan diperoleh melalui sebuah pengalaman yang harus tunduk terhadap pengetahuan rasional, dan pengetahuan rasional harus tunduk terhadap norma-norma agama yang berasal dari Tuhan.

Keempat, keimanan dan nilai-nilai harus diakui sebagai dasar kebudayaan manusia. Oleh sebab itu, keduanya tidak boleh dipisahkan dalam proses belajar mengajar. Ilmu pengetahuan tidak harus ditunjukkan sebagai sesuatu yang bertentangan dengan pandangan agama. Dengan demikian, dalam pendidikan hal itu harus digunakan untuk mendorong nilai-nilai yang baik.

Kelima, peserta didik harus didorong untuk mengetahui prinsi-prinsip unity and diversity dan menyadari adanya dasar-dasar keamanan yang menembus dunia biologis dan psikis. Ini sebuah refleksi terhadap kesatuan prinsip-prinsip pencapaian dunia. Dunia adalah sebuah sistem yang mempersatukan dan terdapat suatu hubungan integral diantara bagian-bagian yang berbeda-beda.

Selanjutnya, untuk merumuskan tujuan melalui kurikulum tentang strateggi pengajaran berbasis multikultural, Suniti mengutip pendapat John Dewey mengemukakan bahwa pendidikan multikultural seharusnya memfokuskan pada kurikulum yang berkaitan langusng dengan pemberian pengalaman sehari-hari siswa. Dengan mempersiapkan peserta didik untuk aktivitas kehidupan tertentu, pendidikan memungkinkan peserta didik untuk mampu memecahkan masalah-masalah mereka hadapi secara teratur, terutama terkait diversitas sosial yang menjadi fenomena empiris peserta didik. Dengan demikian pendidikan multikultural dapat dikembangkan unutk diarahkan pada beberapa kompetensi dasar, diantaranya: ${ }^{20}$

\footnotetext{
${ }^{19}$ Syamsul Mu'arif, Pendidikan Pluralisme di Indonesia, (Jogjakarta: Rake Sarasin, 2000), 102.

${ }^{20}$ Suniti, "Kurikulum Berbasis Multikultural”, Edueksos, Vol III No 2, Juli 2014, 38.
} 
1. Mengembangkan kompetensi akademik standar dasar (standar and basic academic skills) dalam tujuan pendidikan secara umum dan pengajaran secara khusus tentang nilai persatuan dan kesatuan, demokrasi, keadilan, kebebasan, persamaan derajat atau saling menghargai dalam beraneka jenis keragaman.

2. Mengembangkan kompetensi sosial agar dapat menumbuhkan pemahaman yang lebih baik ( $a$ better understanding) tentang latar belakang budaya dan agama sendiri dan juga budaya dan agama lain dalam masyarakat.

3. Mengembangkan kompetensi akademik untuk menganalisis dan membuat keputusan yang cerdas (intelligent decisions) tentang isu-isu dan masalah keseharian (real-life problems) melalui sebuah proses demokratis atau penyelidikan dialogis (dialogical inquiry).

4. Membantu mengkonseptualisasi dan mengaspirasikan konstruksi masyarakat yang lebih baik, demokratis, dan egaliter tanpa ada diskriminasi, penindasan, dan pelanggaran terhadap nilai-nilai yang universal.

Melalui deskripsi singkat tentang model hubungan antara kurikulum dan pengajaran, serta urgensitas nilai-nilai multicultural dalam dunia pendidikan, maka penulis cenderung lebih memilih model siklus (the cyclical model) sebagai model yang tepat terkait hubungan antara kurikulum dengan pengajaran berbasis multikultural. Rasionalisasi sangat sederhana, karena dalam pandangan penulis model ini menggambarkan hubungan timbal balik antara kurikulum sebagai learning experience di satu sisi, dan pengajaran sebagai aktifitas interaksional antara pendidik dan peserta didik di sisi yang lain. Keduanya dapat mempengaruhi antar satu dengan yang lain tanpa harus menegasikan eksistensi masing-masing, antara mana yang mendominasi dan aspek apa yang harus diposisikan sebagai subordinat, sebagaimana model konsentris (concentric model).

Hal inilah yang diinginkan oleh James A Bank yang mengatakan bahwa pendidikan multikultural dapat terlaksana dengan sukses manakala dilakukan perubahan atau improvisasi kelembagaan, termasuk di dalamnya adalah mendesain atau merancang kurikulum yang meliputi materi ajar; pengajaran dan gaya pengajaran, yang meliputi; sikap, persepsi, dan perilaku guru dan administrator. ${ }^{21}$

\section{Kesimpulan}

Pengajaran berbasis multicultural merupakan manifestasi dari UU Sisdiknas No 20 Tahun 2003 tentang tatalaksana penyelenggaraan Pendidikan, serta Peraturan Menteri Pendidikan Nasional No 22 Tahun 2006 tentang standar isi bagi sekolah dasar dan menengah yang mengedepankan hak asasi manusia dan kemajemukan bangsa sebagai subject matter dalam aspek pembelajaran. Kesalingterkaitan ini, meniscayakan model siklus menjaid pilihan yang tepat dalam mengimplementasikan pendidikan

${ }^{21}$ There is general agreement among most scholars and researchers that, for multicultural education to be implemented successfully, institutional changes must be made, including changes in the curriculum; the teaching materials; teaching and learning styles; the attitudes, perceptions, and behaviors of teachers and administrators: and the goals, norms, and culture of the school, selengkapnya lacak dalam James A. Bank, Multikultural Educatian: Historical Development, Dimentions and Practrice” In Review of Research in Education, vol. 19, 4. 
multicultural secara nasional. Karena secara regulatif, isu-isu multikultural telah tercover dalam kurikulum nasional. Sehingga dalam konteks ini, bahwa segala yang ditentukan dalam kurikulum akan menjadi dasar pertimbangan dalam proses pelaksanaan pengajaran. Namun juga sebaliknya, dalam proses pengajaran dapat dijadikan sebagai feedback untuk mereformulasi kurikulum agar sesuai dengan karakter kebudayaan bangsa, terutama Indonesia.

\section{DAFTAR PUSTAKA}

Ali,Moh, Pengembangan Kurikulum di Sekolah. Jakarta : CV. Sinar Baru, 1992.

Banks, James .A, "Multikultural Educatian: Historical Development, Dimentions and Practrice" In Review of Research in Education, vol. 19, edited by L. DarlingHammond. Washington, D.C : American Educational Research Association, 1993.

Bennett, C. \& E Spalding, "Teaching the Social Studies: Multiple Approaches for Multiple Perspectives" In Theory and Reseach in Social Education, 1992.

Farris, P.J \& S.M Cooper, Elementary Social Studies: a Whole language Approach. Iowa: Brown \& Benchmark Publishers, 1994.

Hamalik, Oemar, Proses Belajar Mengajar, (Jakarta : PT Bumi Aksara, 2011.

Idi, Abdullah Pengembangan Kurikulum Teori Dan Praktek,. Jogjakarta : Ar-Ruzz Media, 2011.

Liliweri, Alo, Prasangka \& Konflik: Komunikasi Lintas Budaya Masyarakat Multikultural. Yogyakarta: LKiS, 2005.

Mu'arif, Syamsul, Pendidikan Pluralisme di Indonesia. Jogjakarta: Rake Sarasin, 2000.

Muhaimin, Pengembangan Kurikulum Pendidikan Agama Islam. Jakarta : Rajawali Pers, 2010.

Nasution, Pengembangan Kurikulum. Bandung: Alumni, 1988.

Oliva, Peter F. Developing the Curriculum, third edition. New York. Harper Collins Publishers, 1992.

Smith, Mark K. Curriculum Theory and Practice. London: Routladge, 2002.

Savage, T.V \& Armstrong, D.G, Effective Teaching in Elementary Social Studies Ohio: Prentice Hall, 1996.

Skeel, D.J, Elementary Social Studies: Challenge for Tomarrow"s World. New York: Harcourt Brace College Publishers, 1995.

Suniti, “Kurikulum Berbasis Multikultural”, Edueksos, Vol III No 2, Juli 2014. 


\section{Peraturan Pemerintah/ Undang-Undang}

1. Peraturan Menteri Pendidikan Nasional No 22 Tahun 2006 tentang Standart Isi untuk Satuan Pendidikan Dasar dan Menengah.

2. Undang-Undang Sistem Pendidikan Nasional No 20 Tahun 2003. 